\title{
The Effect of Education on Democracy: Panel Data Analysis of High Income Countries
}

\author{
Çiğdem Karış, ${ }^{1, *}$, Dilek Tandoğan ${ }^{2}$ \\ ${ }^{1}$ Vakfikebir Vocational School, Trabzon University, Trabzon, Turkey \\ ${ }^{2}$ Vocational school of Tourism and Hospitality, Trabzon University, Trabzon, Turkey \\ Received September 17, 2019; Revised October 4, 2019; Accepted October 14, 2019
}

Copyright $\bigcirc 2019$ by authors, all rights reserved. Authors agree that this article remains permanently open access under the terms of the Creative Commons Attribution License 4.0 International License

\begin{abstract}
The aim of this study is to determine the effect of education on democracy. Regions having developed democracy are the centers of attraction that individuals prefer to live in. From this point of view, the whole society's benefitting from individual freedom and equality, which are the basic building blocks of democracy, are closely related to the existence of educated individuals who make up that democratic society. Therefore, it can be stated that societies with a high level of education are of a high level of democracy. For this purpose, panel data method was used to measure the effect of education on democracy for high income country group in the period of 1990 and 2015 and the effect of education on democracy was investigated. According to the findings, it was found out that education had a positive effect on democracy. Since the selected country group has a high level of education, the finding reveals the importance of educated individuals for advanced democracy. Therefore, the result of this study supports the view that one of the factors that have a high level of development in high-income countries compared to other advanced democratic also contributes to this study.
\end{abstract}

Keywords Education, Democracy, Panel Regression

JEL Classification: C23, I25

\section{Introduction}

Democracy is an understanding of governance that facilitates living together for individuals and is preferred in today's world, along with its fundamental concepts such as supremacy of law, legal equality, personal freedoms, power to change the governance, right to elect and be elected and property rights. In modern societies, individuals do not want to confront any problems in expressing themselves and choosing freely. Thus, regions having a developed democracy are becoming the center of attraction for individuals to live nowadays. Acemoglu and Robinson (2013) in their studies aiming to determine the reasons for these differences in countries that are close to each other in terms of geography or culture and whose living conditions are different from each other attribute these differences to the processes of democracy between these countries. For instance, they related the causes of difference to the process of democratization in the regions having quite high levels of income inequality despite being very similar in terms of geography, culture and climate, such as South America and North America or North Korea and South Korea. Compared to exploitative institutions, inclusive institutions have contributed prominently to the income level and living conditions of the societies they are included in, with an understanding of governance established on a democratic basis and based on the principles of justice, law and equality. Therefore, it is important to determine the impact of developed democracy processes among the reasons that are ahead when developed countries are compared in terms of income differences with countries with low democracy. Because this information can make a positive contribution to countries in their efforts to increase their welfare. From this point of view, the importance of identifying the factors causing advanced democracy becomes clear. In this context, it is important to have educated individuals who can make effective decisions in order to correctly perceive and operate these advantages of democracy. As a matter of fact, the functioning of democracy depends on the right decisions to be taken and thus necessitates the existence of educated individuals.

Nonetheless, the presence of educated individuals who can make efficient decisions for these supremacies, which are included in democracy, to be perceived and function in a correct way is very important. It depends on the right decisions to be taken and thus, requires the presence of 
educated individuals for democracy to function correctly. To put it more explicitly, education is an effective means to raise individuals who have free will and thought, can make right decisions and look after his/her own interests and thus the society's, for an efficient democracy. At this point, state governments emphasizing the fact that education is the building block in their plans of assessing processes that have an influence on the development of welfare support the subject in question. Individuals who are educated, have free will and are able to analyse their choices and their results are aware that looking after the interests of society carries importance for total utility and sustainability. By this way, this situation will form a basis for an environment of conciliation where individual differences are respected and conflict environment is minimised for themselves and the next generations. This situation will also provide a basis for the improvement of societies, with the increase in the number of happy individuals.

Considering the contribution of education at this point, Dewey (1916) emphasizes that democracy depends on education and planned and systematic education needs to be given importance in the process of democratization (Dewey, 1916:101). Lipset (1959) states that education acts as a means for democracy. In the literature, Lipset's hypothesis highlighting the relationship between democracy and education indicates the presence of a sustainable democracy in the countries that have a high level of education. Lipset reveals the relationship between democracy and education by stating that the countries having a sustainable democracy also have high levels of education. He suggests that the countries having a well-educated population mostly also have a higher level of democracy and this hypothesis is supported by available data. While the literacy rate in Europe's more democratic countries is $96 \%$, it is $85 \%$ in less democratic countries. The relevant data in Latin America is equal to average 74\% for less dictatorship countries while it is equal to $46 \%$ in more dictatorship countries. Some questions were addressed to individuals living in different countries about their beliefs in various democratic norms for the opposition, their attitude against ethnical or racial minorities and their beliefs on single-party systems against multi-party systems, to evaluate their attitudes. The findings obtained showed that the most important and only factor that separates the ones giving a democratic reaction from the others was education (Lipset, 1959: 78-79).

For a democratic and stable society, some mutual values of society should be accepted by large masses and majority of individuals should be knowledgeable and have a minimum level of literacy at least. At this point, education contributes to both. Consequently, the income earned from a child's education accrues not only to the child and his/her family, but also to the other members of society. The child's education contributes to welfare by supporting a stable and democratic society (Friedman, 1962:75).
It is claimed that education contributes to the development of democracy culture which brings along a higher welfare, by supporting political development as much as supporting democracy (Acemoglu et al., 2005:44). In the relationship between education and democracy, the presence of educated individuals will provide milder results in accepting the rights of individuals connected with the opposition or marginal groups and thus, supporting democratic principles. The second view emphasizes the link between education and participation. It ensures to support the political interests and civic skills by increasing the possibility of political participation. The third view suggests that education increases social equality (Aleman and Kim, 2015:1-2).

For this purpose, the effect of education on democracy with high income countries was examined with the help of panel data method. In line with this objective, the effect of education on democracy in high income group countries is set as the subject of the study. In the second part of the study, studies related to the subject in question are examined and presented as summary. In the third and fourth sections, the findings obtained by data set and econometric method are given. In the last part, results of the study are evaluated according to the findings obtained.

\section{Literature Review}

In this part of the study, studies examining the relationship between education and democracy are presented as summary including country, period, method and results. The pioneering studies on the relationship between democracy and education have been examined on a theoretical basis with Dewey (1916), Lipset (1959) and Friedman (1962). These studies show that education supports democracy. On the other hand, when the studies related to the subject are examined in the literature, it is seen that different countries and methods are used and there are also different results.

For example, Apergis (2018), in his study that applied panel causality method for 161 countries, identified a bidirectional causality relationship between democracy and education. On the other hand, Dahlum and Knutsen (2017), in the study of 120 cross-sectional methods for 120 countries found that democracy positively affects education. Aleman and Kim (2015) found that for 133 and 140 countries, education positively affected democracy. Similarly, Bittencourt (2013), in his study using panel method for 15 Sub-Saharan African countries, found that education affects democracy positively. Mulligan et al. (2004), in their studies using the cross-sectional method for 26 countries could not detect a relationship between education and democracy. Similarly, Acemoglu et al. (2005), in their studies using panel data method, revealed that education does not affect democracy. Acemoglu et al. (2005) attribute the different results of the studies to the use 
of missing data in explanatory variables affecting democracy. In other words, it is possible to say that the exclusion of some of the variables affecting the relationship between education and democracy prevents similar results. However, when the applied studies examined in the literature are evaluated as a whole, it is seen that education affects the democracy positively in general. For instance, Turedi and Terzi (2017) examined the relationship between democracy and education in Turkey for 1972-2012 period through Sims, Modified Sims and Dolado-Lütkepohl causality tests. Democracy was represented by the average of Freedom House political rights and civil liberties index and education was represented by a number of university graduates, in the study. There was a bidirectional relationship detected between education and democracy as the result of analysis.

Balaev (2014) examine the relationship between democracy and education for 1960-2008 period in 80 countries (high, upper-middle, lower-middle and low-income) through panel corrected standard errors method. Four variables (Polity IV, Freedom House world freedom index, Polyarchy index and democracy index calculated by weighted average of these three variables) are used as the indicator of democracy, while education is represented by the percentage of those who enrolled in university and secondary school. It is determined that education supported democracy according to the findings obtained.

Similarly, Murtin and Wacziarg (2014) examine the relationship between democracy and education in 70 countries for 1870-2000 period via dynamic panel data method. Polity IV is used as the indicator of democracy whereas the average years of schooling in primary school for the population above the age of 15 is used as the indicator of education in the study. According to the findings obtained, it is determined that education affect democracy positively.

Sanborn and Thyne (2014) analyse the relationship between democracy and education for 1970-2008 period in 85 countries using panel data method in their study. Democracy, which is used as dependent variable, is represented by Polity IV Democracy index while education, which is used as independent variable, is represented by the participation in education at different levels (the percentage of the ones who received at least a little education, the percentage of the ones who completed primary school and the percentage of the ones who completed college) obtained by using the data of International Institute of Applied Systems Analysis and the rate of men and women receiving education. According to the findings obtained, there is a positive relationship between the level of education and democracy and also, the increase in the education level of men and women affected democracy positively.

Castello-Climent (2008) examines the relationship between democracy and education in 104 countries for 1970-2000 period via dynamic panel data method. Democracy variable used in the study is represented by Freedom House political rights and civil liberties index while education is represented by the average years of schooling for the age of 25 and above and the percentage of education provided by $60 \%$ of the population. According to the findings obtained, it is determined that education has a positive effect on democracy.

In the other study, Chen (2008) examines the relationship between democracy and education for 8 East Asian countries for 1971-2003 period by using time-series cross-section method. Democracy is represented by Polity IV and education is represented by education spending (education spending as a percentage of total government spending captures budget priorities of the government; education spending as a percentage of gross domestic product (GDP) reflects allocative priorities within the national economies as a whole; and education spending per capita measures potential resources available to citizens). Findings show that education increase as the level of democracy increased.

Moreover, Papaioannou and Siourounis (2008) examine the relationship between democracy and education in 174 countries for 1960-2005 period through cross-sectional analysis. Democracy is represented by Polity Democracy index, Freedom House Political rights and Civil Liberties indexes and classification of regimes of Przeworski et al. $(1996,2000)$ while education is represented by the average years of schooling for the age of 25 and above. According to the findings obtained, it is concluded that there is a higher chance for democracy to emerge and enhance in educated countries.

Bobba and Coviello (2007) research the relationship between democracy and education in 108 countries for 1965-2000 period (five-year) through dynamic panel data method in their study. Democracy, which is used as the dependent variable, is represented by Freedom House Political Rights index while education, which is the independent variable, is represented by the average years of schooling. The results reveal that education has a positive effect on democracy.

Ansell (2006) examines the relationship between democracy and education in 115 countries for 1960-2002 period by using panel data method. Democracy is represented by Polity IV whereas education is represented by public education spending. As the conclusion of analysis, it is detected that democracy affects public education spending positively.

Similarly, Brown and Hunter (2004) examine the relationship between democracy and education in 17 Latin American countries for 1980-1997 period through time-series cross-sectional analysis. Democracy is represented by Polity IV whereas education is represented by the percentage of education spending for pre-school and primary school taking place in total education 
spending. The results reveal that democracy affect education positively.

Barro (1999) examine the relationship between democracy and education in 100 countries for 1960-1995 period through panel data method. Democracy is represented by two variables as the rights of election and civil liberties, whereas education is represented by the difference between the average rate of schooling for the age of 25 and above and the average rate of schooling at secondary school and high school level among men and women aged 25 and above. It is determined that education affect democracy positively according to the results obtained. However, it is determined that the difference between schooling rates of men and women affect democracy negatively.

Brown (1999) examines the effect of democracy on education for 1960-1987 period in 94 developing countries through panel data method. Democracy is represented by Polity III while education is represented by Primary School Enrollment. The findings reveal that democracy affect education positively.

Crenshaw (1995) researches the relationship between democracy and education in 83 countries for 1965-1980 period through cross-sectional analysis in the study. Political Democracy index is used as the indicator of democracy while secondary school enrollment rate is used as the indicator of education variable. The results obtained show that education affect democracy positively.

In conclusion, when examining applied studies analysing the relationship between democracy and education, it is detected that the studies used panel data and cross-sectional method mostly while the number of the studies using time-series method is limited. The findings obtained from the studies reveals that education contributes to democracy in general. In addition, it was determined that developed democracy also increases education.

When the applied studies examining the relationship between education and democracy were evaluated as a whole, it was found that the studies using the time series method when the income level of the studies were done with panel data and cross-sectional method over different countries were limited. Findings from the studies generally show that education contributes to democracy. On the other hand, it is determined that developed democracy also increases education. In addition, it is seen that both the level of democracy and education are high in high income countries. Therefore, determining the effect of education on democracy and determining its positive contribution only for high income countries reveals the importance of this study.

\section{Data Set and Econometric Method}

In the study, education's effect on democracy for 1990-2015 period was analysed by using annual data, through 33 high income group countries ${ }^{1}$ obtained from World Bank's classification.

Following the studies examined in literature, index values published by Freedom House were utilised for the democracy index. Freedom House has been publishing the index values of political rights and civil liberties of countries since 1972. The democracy index was established by taking the arithmetic average of political rights and civil liberties' indexes. Index value varies from 1 to 7. According to this, it reveals the transition to a developed democracy as the index value decreases (approaches to 1) and the transition to an underdeveloped democracy as the index value increases (approaches to 7). Countries are subjected to a triple distinction of status as free, partly free and not-free, in the classification of Freedom House. According to this distinction, the countries taking a value between 1-2,5 are classified as free, the countries taking a value between 3-5 are classified as partly free and the countries taking a value between 5,5-7 are classified as not free. Freedom House collects and evaluates this information with the help of exterior analysts by using the combination of in-situ research, consultations with local liaisons, news articles, non-governmental organizations, governments and information from other various sources ${ }^{2}$. The variable of average years of schooling (Mean Years of Schooling) obtained from UNDP (United Nations Development Programme) was used for the education indicator. Definition of the variables and the source they were obtained from take place in Table 1:

Table 1. Definitions of Variables

\begin{tabular}{|c|c|c|}
\hline $\begin{array}{c}\text { Name of } \\
\text { Variable }\end{array}$ & Definition & Source \\
\hline $\begin{array}{c}\text { Democracy } \\
\text { (Dem) }\end{array}$ & $\begin{array}{c}\text { Dem=Civil Rights + Civil } \\
\text { Liberties } / 2\end{array}$ & $\begin{array}{c}\text { Freedom } \\
\text { House }\end{array}$ \\
\hline Education (Ed) & Mean Years of Schooling & UNDP \\
\hline
\end{tabular}

Education's effect on democracy in high income countries is researched through equation (1) by using balanced panel data method.

$$
\operatorname{Dem}_{i t}=\beta_{0 i}+\underset{1990, \ldots, 2015}{\beta_{1}} E d_{i t}+\beta_{2} E d_{i t-1}+u_{i t}, i=1, \ldots, 33, t=
$$

In equation (1) $i$ indicates country, $t$ indicates time, $\beta_{0 i}$ indicates country fixed effect and $u_{i t}$ indicates error term. $\beta_{1}$ indicates the coefficient revealing how the average period of education affects the level of democracy. Moreover, as the effects of education show themselves later on, $\beta_{2}$ indicates the coefficient revealing how the lagged value of the average period of education affects the level of democracy. Number of the countries is determined as $N=33$ for high income group countries. $t=26$ includes 1990-2015 period.

1 The list of high income group countries is presented in Appendix 1 . 2For more detail, see: https://freedomhouse.org/report-types/freedom-wo rld 
Classical model is valid in case panel regression assumptions are fixed and slope coefficients do not vary according to units and time (in case observations are homogeneous). While classical model is estimated by pooled OLS, it is generally estimated over two models in case varying according to unit and time. Fixed Effects Model (FEM) is used in samples based on a certain group while Random Effects Model (REM) is used in samples randomly drawn from a large mass. In FEM, it is assumed that the difference among units derives from the constant term, whereas in REM, it is assumed that the difference among units takes place as a component of the error term in the model. Considering these information, the method to be used to estimate the panel model is determined as a result of relevant tests. With this aim, F, Breusch-Pagan Lagrange Multiplier (LM) and Hausman tests are used as the appropriate model estimators for choosing the model estimators.

$\mathrm{F}$ test reveals whether the classical model and estimation are valid in panel data model. $\mathrm{H}_{0}$ hypothesis reveals that there are no time and unit effects while alternative hypothesis reveals that in the model in which time and unit effects are present, $\mathrm{H}_{0}$ hypothesis' estimation of not being rejected can be solved by classical (pooled OLS) model or else the classical model solution is not valid (FEM is valid).

Chow and Breush Pagan (BP) test is used to compare classical (OLS) model with fixed effects model. Accordingly, $\mathrm{H}_{0}$ hypothesis reveals that it is more appropriate to choose classical model while alternative hypothesis reveals that it is more appropriate to choose fixed effects model.

Breusch-Pagan Lagrange Multiplier (LM) test is used to compare random effects model with classical (pooled OLS) model. Accordingly, $\mathrm{H}_{0}$ hypothesis is formed as the variance of unit effects is zero and alternative hypothesis is formed as the variance is different from zero. According to this, $\mathrm{H}_{0}$ hypothesis not being rejected shows that the model can be solved by classical (pooled OLS) model or else random effects model estimate is more appropriate than pooled model. Whether the error term is correlated with explanatory variables, in other words whether REM is the appropriate model, is determined by Hausman testing (Guajarati and Porter, 2012: 603). Accordingly, choosing REM is appropriate if there is no correlation detected between error term and explanatory variables. In other saying, while $\mathrm{H}_{0}$ hypothesis chooses random effects estimator, alternative hypothesis reveals that fixed effects estimator is consistent.

\section{Econometric Results}

Table 2 shows the estimation results of Pooled OLS, FEM, REM and Robust estimator of the model established in order to determine education's effect on democracy for high income group countries.

Table 2. Estimation Results of Pooled Ols, Fem, Rem and Robust

\begin{tabular}{|c|c|c|c|c|}
\hline & Pooled OLS & FEM & REM & Robust Estimator \\
\hline $\mathrm{c}$ & $7.071635^{\mathrm{a}}(0.4065655)$ & $\begin{array}{c}6.268982^{\mathrm{a}} \\
(0.2623998)\end{array}$ & $\begin{array}{c}6.287345^{\mathrm{a}} \\
(0.2660507)\end{array}$ & $\begin{array}{c}6.287345^{\mathrm{a}} \\
(0.9758602) \\
\end{array}$ \\
\hline led & $-0.0293614(0.1016954)$ & $-0.0137048(0.0482727)$ & $-0.0145467(0.048365)$ & $-0.0145467(0.0655104)$ \\
\hline led(-1) & $\begin{array}{l}-0.3011614^{\mathrm{a}} \\
(0.0999655) \\
\end{array}$ & $\begin{array}{l}-0.2010366^{\mathrm{a}} \\
(0.0474776) \\
\end{array}$ & $\begin{array}{l}-0.2028427^{\mathrm{a}} \\
(0.0475679) \\
\end{array}$ & $\begin{array}{l}-0.2028427^{\mathrm{a}} \\
(0.0755288)\end{array}$ \\
\hline $\mathrm{R}^{2}$ & 0.0401 & 0.0451 & 0.0451 & 0.0451 \\
\hline $\mathrm{F}$ test & $17.17 \mathrm{a}$ & $99.14^{\mathrm{a}}$ & & \\
\hline LM Test & & & $6171.94^{\mathrm{a}}$ & \\
\hline Hausman & & & 0.82 & \\
\hline \multicolumn{5}{|c|}{ Diagnostic Tests } \\
\hline Baltagi-Wu LBI & & & 0.42114475 & \\
\hline $\begin{array}{l}\text { Levene, Brown, Forsythe } \\
\text { Heteroscedasticity Tests }\end{array}$ & & & $\begin{aligned} \mathrm{W}_{0} & =58.802476^{\mathrm{a}} \\
\mathrm{W}_{50} & =15.357715^{\mathrm{a}} \\
\mathrm{W}_{10} & =53.546604^{\mathrm{a}}\end{aligned}$ & \\
\hline Pesaran CD LM & & & $9.807^{\mathrm{a}}$ & \\
\hline
\end{tabular}


As it is seen in Table 2, F test statistic revealed that the model is not appropriate to be estimated by Pooled OLS as $\mathrm{H}_{0}$ hypothesis is rejected at $1 \%$ level of significance. Similarly, F test statistics revealed that the model cannot be solved by Pooled OLS as $\mathrm{H}_{0}$ hypothesis is rejected at $1 \%$ level of significance. Furthermore, the result of Hausman test statistic applied to reveal the validity of REM estimation results determined that it is appropriate that $\mathrm{H}_{0}$ hypothesis cannot be rejected and the model is estimated by REM. At this stage, it is researched through diagnostic tests whether the established model is the appropriate one. As it is seen in Table 2, heteroscedasticity problem was tested by Levene, Brown, Forsythe tests. The findings obtained showed that there was a heteroscedasticity problem with the rejection of $\mathrm{H}_{0}$ hypothesis at $1 \%$ level of statistical significance. Autocorrelation problem was determined by Baltagi-Wu LBI test. As it is seen in Table 2, the autocorrelation problem was detected as test statistic was far away from 2. Similarly, cross-sectional dependence was researched through Pesaran CV LM test. Results showed that there was a cross-sectional dependence problem as $\mathrm{H}_{0}$ hypothesis was rejected at $1 \%$ level of significance. In this case, the model was re-estimated by using robust estimator method as the established model had these three problems. As it is seen in Table 2, education coefficient was detected as negative and statistically insignificant. Moreover, it was determined that education being delayed by one term affected democracy variable negatively at $1 \%$ level of statistical significance.

To put it more clearly, the negative result shows that education affects democracy positively because as the index value used as the indicator of democracy increases it indicates an underdeveloped democracy and as it decreases, it indicates a developed democracy. According to the findings obtained, $1 \%$ increase in the first delay of education increases democracy by $0.2 \%$.

\section{Discussion and Conclusions}

It is revealed by the studies that as the level of education increases, the level of democracy increases. Education ensures to take efficient decisions in supporting the understanding of democracy and enhances the benefit of society. It is observed that individuals are able to make decisions in favor of society and perform social attitudes and behaviors facilitating living together, as the level of education increases.

Thus, education is seen as an important means for democracy to be the correct way of governance that may be in favor of the society. Thus, how education affects democracy for 33 countries taking place high income group in which the level of education and democracy is high was determined as the subject of the study. Education's effect on democracy was estimated by REM estimation of panel regression model for 1990-2015 period. The findings revealed that a delay of education increased the level of democracy. In other words, it was determined that an increase by $1 \%$ in a lagged value of education increased the level of democracy by $0.2 \%$.

This result supports the findings of Aleman and Kim (2015), Bittencourt (2013), Ansell (2006) and Brown (1999). On the other hand, as Acemoglu and Rabinson (2013) stated in their studies, as the income differences between countries are in favour of the countries with developed democracy, this study led to the selection of the world's leading high-income country group in both income level and in the processes of democracy. The results of the study determined that education positively affects democracy for high income country group. This result plays a significant role in terms of empirically demonstrating the importance of education for developed democracy discussed in the studies of Acemoglu and Rabinson (2013).

Democracy is an understanding of governance promoting today's societies' living in peace through its contribution to social decision-making mechanism. Thus, it reveals the importance of this study that education affects democracy positively by supporting modern life and causing less of a conflict environment at the same time.

\section{Appendix 1: High Income Group Countries List}

\begin{tabular}{|c|c|c|}
\hline 1. Australia & 12. Greece & 23. Norway \\
\hline 2. Austria & 13. Hungary & 24. Poland \\
\hline 3. Barbados & 14. Iceland & 25. Portugal \\
\hline 4. Belgium & 15. Ireland & 26. Singapore \\
\hline 5. Canada & 16. Israel & 27. Spain \\
\hline 6. Chile & 17. Italy & 28. Sweden \\
\hline 7. Cyprus & 18. Japan & 29. Switzerland \\
\hline 8. Denmark & 19. Luxembourg & 30. Trinidad and Tobago \\
\hline 9. Finland & 20. Malta & 31. United Kingdom \\
\hline 10. France & 21. Netherlands & 32. United States \\
\hline 11. Germany & 22. New Zealand & 33. Uruguay \\
\hline
\end{tabular}

\section{REFERENCES}

[1] Acemoglu, D. J., Simon, R., James A., \& Yared, P. (2005). From Education to Democracy? The American Economic Review, 95(2), 44-49.

[2] Acemoglu, D., \& Robinson, J. A. (2013). Why Nations Fail the Origins of Power, Prosperity, and Poverty, (F. R. Velioğlu, rans). Istanbul: Doğan Egmont Publishing and Production Trading Inc.

[3] Aleman, E., \& Kim, Y. (2015). The Democratizing Effect of Education. Research and Politics, 1-7. 
[4] Ansell, B. (2006). Traders, Teachers, and Tyrants: Democracy, Globalization, and Public Investment in Education. Weatherhead Center for International Affairs Working Paper, 06-01, Retrieved from https://wcfia.harvar d.edu/files/wcfia/files/1060_ba_tradesteachers.pdf

[5] Apergis, N. (2018). Education and Democracy: New Evidence from 161 Countries. Economic Modelling, 71, 59-67.

[6] Balaev, M. (2014). Improving Models of Democracy: The Example of Lagged Effects of Economic Development, Education, and Gender Equality. Social Science Research, 46, 169-183.

[7] Barro, R. J. (1999). Determinants of Democracy. Journal of Political Economy, 107(S6), 158-183.

[8] Bittencourt, M. (2013). Democracy and Education: Evidence from the Southern African Development Community. University of Pretoria Working Paper, 2013-87, Retrieved fromhttps://www.up.ac.za/media/share d/61/WP/wp_2013_87.zp39596.pdf.

[9] Bobba, M., \& Coviello, D. (2007). Weak Instruments and Weak Identification, in Estimating the Effects of Education, on Democracy. Economics Letters, 96(3), 301-306.

[10] Brown, D. S. (1999). Reading, Writing, and Regime Type: Democracy's Impact on Primary School Enrollment. Political Research Quarterly, 52(4), 681-707.

[11] Brown, D. S, \& Hunter, W. (2004). Democracy and Human Capital Formation: Education Spending in Latin America, 1980 to 1997. Comparative Political Studies, 37, 842-864.

[12] Castello-Climent, A. (2008). On the Distribution of Education and Democracy. Journal of Development Economics, 87, 179-190.

[13] Chen, J. (2008). Democratization and Government Education Provision in East Asia. Journal of East Asian Studies, 8(2), 175-209.

[14] Crenshaw, E. M. (1995), Democracy and Demographic Inheritance: The Influence of Modernity and Proto-Modernity on Political and Civil Rights, 1965 to 1980. American Sociological Review, 60(5), 702-718.

[15] Dewey, J. (1916), Democracy and Education: An Introduction to the Philosophy of Education, New York: The Macmillan Company, Retrieved from https://en.wikiso urce.org/wiki/Democracy and Education.

[16] Dahlum, S., \& Knutsen, C. H. (2017). Do Democracies Provide Better Education? Revisisting the Democracy-Human Capital Link. World Development, 94, 186-199.

[17] Friedman, M. (1962). Capitalism and Freedom. Chicago: University of Chicago Press.

[18] Gujarati, D. N. and Porter, D., (2009). Basic Econometrics (5th Ed.). New York: Mcgraw-Hill International Edition.

[19] Lipset, S. M. (1959). Some Social Requisites of Democracy: Economic Development and Political Legitimacy. The American Political Science Review, 3(1), 69-105.

[20] Mulligan, C. B., Gil, R., \& Sala-i Martin, X. (2004). Do Democracies Have Different Public Policies than
Nondemocracies. Journal of Economic Perspectives, 18(1), $51-74$.

[21] Murtin, F., \& Wacziarg, R. (2014). The Democratic Transition. Journal of Economic Growth, 19, 141-181.

[22] Papaioannou, E., \& Siourounis, G. (2008). Economic and Social Factors Driving the Third Wave of Democratization. Journal of Comparative Economics, 36, 365-387.

[23] Sanborn, H., \& Thyne, C. L. (2013). Learning Democracy: Education and the Fall of Authoritarian Regimes. British Journal of Political Science, 44, 773-797.

[24] Turedi, S., \& Terzi, H. (2017). The Relationship between Education and Democracy in Turkey. Studies on Balkan and Near Eastern Social Sciences, Rasim Yilmaz / Günther Löschnigg (eds.), Frankfurt am Main: Peter Lang, Retrieved from https://www.researchgate.net/publication/3 11934934_The_Relationship_between_Education_and_De mocracy_in_Turkey. 